\title{
The Sovereign Butterflies of Saskatchewan
}

\author{
By DONALD HOOPER, Somme, Sask.
}

There are five species of butterflies of the genus Limenitus found in North America. There used to be seven species listed but two of these have been changed to subspecis. Two of the species are found commonly in Saskatchewan and a third might possibly be found in southwestern Saskatchewan. The Sovereign butterflies hibernate as partly grown larvae. In Saskatchewan, they have one or two broods, according to seasonal climatic conditions.

VICEROL OR MIMIC. Limenitis archippus. This is a bright orange butterfly. The margins of the wings have white spots, and the veins are black. The Viceroy closely resembles the Monarch Butterfly, but it is smaller with a wing expanse of about $23 / 4$ inches and a black line crossing the hind wing. The Viceroy is often called the Mimic because of this resemblance to the Monarch. Birds do not eat Monarch Butterflies because they are distasteful to them, and it is believed that birds do not eat Viceroys either because they resemble Monarchs.

The Viceroy is found commonly throughout southern and central Saskatchewan. Probably it does not range far north in Saskatchewan as it is not found in the Northwest Territories. The caterpillars feed on willows, poplars, aspens, plum, apple and cherry. The Viceroys are very fond of flowers. I took the accompanying photograph of one last summer on a fleabane blossom.

WHITE ADMIRAL OR BANDED PURPLE. Limenitis arthemis rufrofasciata. This is a black butterfly with a white band across its wings. There is a row of red dots on the hind wing and a submarginal row of blue dashes on the fore and hind wings. The wing expanse is about three inches. The Banded Purple is commonly found in Saskatchewan and well into the Northwest Territories.

Banded Purples are very fond of flowers, cow parsnip being one of the favourites. The caterpillars feed on birch, willow, aspen, poplar and hawthorn.

WEIDEMEYER'S ADMIRAL. Limenitis weidermeyeri. As far as I know, this species has not yet been found in Saskatchewan, but it should be looked for in the southwest corner of the province, as it has been taken at Big Sandy, Montana, about 60 miles from the border. The species closely resembles the Banded Purple but the submarginal dashes on the wings are white instead of blue. The caterpillar feeds on cottonwood.

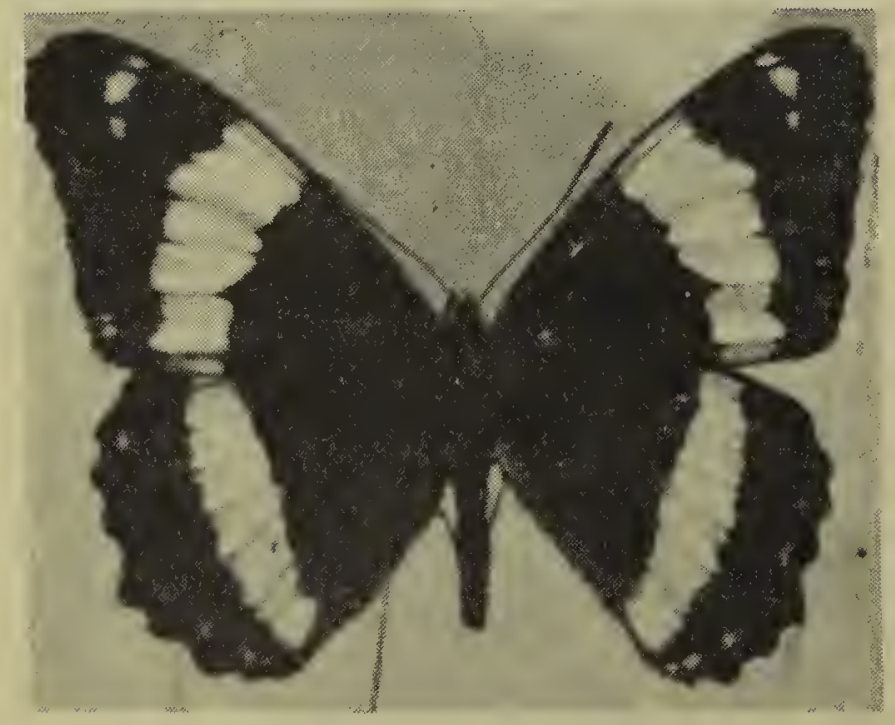

White Admiral or Banded Purple

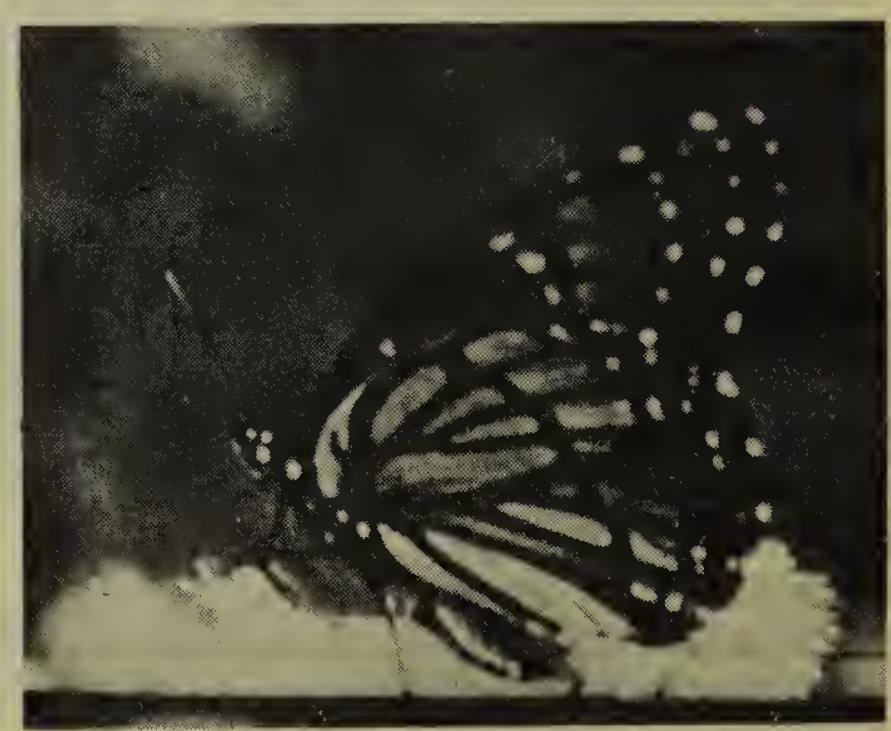

Viceroy or Mimic 